\title{
Softening Borders: Reconceptualizing the Role of Education for Inclusiveness of Refugees and Immigrants
}

\author{
Shirley McLoughlin \\ Keene State College
}

Crossing borders, whether geo-political, racial, religious, or gender related, requires acknowledgement of the perception of borders, and willingness to accept individual discomfort that accompanies these journeys. To soften the many borders faced by refugees, we need more inclusive classrooms, communities, and countries. This begins with how we teach our students and present counternarratives to those embraced in the nationalist environments where many of us reside. Using specific pedagogical approaches will facilitate sustainable support and growth of all engaged in this process, resulting in personal, institutional, and community based efforts to provide environments where all individuals can create meaningful, productive lives.

Keywords: inclusiveness, refugees, immigrants, education

\section{INTRODUCTION}

When considering the concept of border crossing, it is often initially conceived in terms of geopolitical borders. Indeed, the crossing of geopolitical borders has been an impetus for some of the best and worst examples of historical events in humankind, destroying cultures, initiating wars, developing collaborative communities, impacting arts and humanities, and moving forward in technological and scientific discoveries, to name a few. Despite the oft reminded adage of "learning from the past," unfortunately we find some of the worst examples of "history repeating itself" occurring in today's world. We must counter these negative circumstances with targeted educational approaches in our classrooms that help to ensure that future generations will have the tools to fight against marginalization and discrimination of those border crossers who are not considered part of dominant society.

In the near past, the use of the term "border crossing" took on a broader scope of meaning, going beyond the rigidity of geographical borders to encompass cultural and societal borders, and the fluidity that sometimes occurs along these borders. Such was introduced in Giroux's work, Border Crossings: Cultural Workers and the Politics of Education (2005). Giroux examines the role of education in transcending borders - especially those that relate to power, highlighting the impact of social standing, economic factors, and race/ethnicity. To many of educators who were exposed to these ideas over a decade ago through much reading, discussion, lived experiences, and reflection, when we heard the term border, we began to consider areas/walls/policies/etc. that frequently strengthen the marginalization of those not in the dominant, ruling components of a society. We thought of race, gender, LGBTQ+ components, ethnicity, ability, religion, socioeconomic factors, and the impact of intersectionality when more than one of these factors exist. Yet, fourteen years after Giroux's publication, we are undeniably 
returned to the concept of geopolitical borders, with the Syrian refugee crisis and its political and societal impact on the refugees, the European Union, and Turkey. We are returned to these borders with the United States' changing approaches to immigration and refugees, and the recent the crisis in Sudan and other countries in Africa. Clearly, this is a growing global concern, with numbers of forcibly displaced individuals reaching record highs at 70.8 million people by the end of 2018 (UNHCOR, 2018).

While the return to examining this conceptualization of geopolitical borders is important, we must be inclusive of the other borders these refugees and immigrants must confront, in addition to the hardships, the pain, the suffering, and the loss that often accompanies their treks. They are frequently faced with borders related to gender, to race, ability, etc. when they pause in their journeys or begin new lives in their new countries. It is critical that we work towards softening these borders, making them less defined, and perhaps, seeing them as a fertile place for mutual intercultural dialogue, sharing, support and appreciation. Clearly, education is a key component in the process of softening these borders.

\section{MARGINALIZATION}

The marginalization that faces refugees and immigrants is not in just one specific area, but instead falls in a multitude of areas. Refugees are frequently seen as "the Other," outsiders from dominant society, and depictions in media and other communications often reinforce this. In addition to gender, race, ethnicity, and class, other areas are often overlooked as sources of marginalization of refugees, including but not limited to mothering styles (Dever, 2006; Ramsey, 2016), non-adherence to the society's heteronormativity, language difference (McDonald \& O'Sullivan, 2018), health (Yotebieng, 2017) and stereotyping, i.e. assumptions about all refugees from said country or area. Kisiara (2015) suggests that one often overlooked component of stereotyping includes reiteration of their suffering, i.e. instead of a focus on their strength, wisdom, and fortitude in reaching their new location. Regardless of the specific types of marginalization, it must be noted that when an individual faces marginalization in more than one area, this becomes especially difficult.

As noted critical race theorist Kimberly Crenshaw (1995) pointed out in her groundbreaking work on intersectionality, "Race, gender, and other identity categories are most often treated in mainstream liberal discourse as vestiges of bias or domination" (p. 357). She notes

Intersectionality is a lens through which you can see where power comes and collides, where it interlocks and intersects. It's not simply that there's a race problem here, a gender problem here, and a class or LBGTQ problem there. Many times that framework erases what happens to people who are subject to all of these things (2017)

If we apply this to refugees, we can see that for many, there exists not one area of marginalization, but many, and when these are combined, they worsen the oppression experienced in a much greater manner than by merely experiencing these areas of marginalization separately, i.e. there is intersectionality occurring here. There are overlapping areas of oppression, increasing the inequity of the individuals' places in society. Moreover, Krenshaw (2009) notes that if we examine each area of marginalization separately, "fail[ing] to acknowledge the significance of the other, the power relations that each attempts to challenge are strengthened" (p. 236).

I will argue that the key to working to bring these situations to light is education - both formal and informal. Without education, we cannot bring about the change required to address the often deplorable situations existing for the millions of displaced persons in the world. It can start with our higher education students, many of whom have not been exposed to a different way of examining these issues. We cannot sit back, understanding what is at stake here, yet still teach the same old curriculum in higher education. As McLaren (2015) reminds us,

not knowing is not the same as ignorance...the truly authentic ...educator...create[s] new forms of knowing, forms in which justice is externally struggled for and inwardly 
impressed, where knowledge is more enacted than spoken, where it becomes perpetually transfigured along with the agency of the learner (p.250)

We must infuse our curriculum with stories of "the Other," we must question policy by asking "who does this privilege, who does this ignore, or even worse, hurt?. We must consider what are we ignoring or not understanding as members of mainstream society, what are prominent issues in the lives of refugees and other marginalized groups. We must be willing to face resistance, not only from students, but also from our colleagues, and, at times, our administration. At time, we will need to be creative, and at times, perhaps even a bit subversive to continue this work and still keep our jobs. That is why it is critical that we, as both formal and informal educators, work to understand the challenges refugees face, to allow refugees' voices to be heard, and to provide counternarratives to the representations of refugees in the media and from other sources, especially if we are doing this work in environments currently favoring nationalist administrations.

Some of us are fortunate to work in environments that are diverse and respectful to the varied voices within our surroundings. For those of us who are not so fortunate, it can be difficult to work with our college students and it can be even more difficult to work with our colleagues within our department. There are pedagogical tools and techniques that have worked over time in my work in these areas. None of these are quick, easy fixes - they require patience, reinforcement, and a positive attitude that the work being done is important and meaningful. Faculty must be aware that they may not personally see the results of their work in a semester. They may only be doing the proverbial planting of seeds - some of which take much longer to germinate than others. After all, it took generations to have acceptance of some of the hateful rhetoric we have heard from world leaders today - it will take time to undo this damage.

\section{EDUCATIONAL CONSIDERATIONS}

Paulo Freire (2001), renowned educational theorist, worked with illiterate peasants in Brazil and this work greatly influenced his work, Pedagogy of the Oppressed (2000). He recognized that the standard curriculum taught in schools often resulted in replicating the societal power structure, allowing little to no chance of those not in the dominant, ruling classes to acquire stronger voices (or any voices) in societal power systems. The root of much of our work is in the unequal distribution of power.

Using Gramscian hegenomic theory, we can deconstruct societal paradigms, examining how power is constructed by the dominant class over the subordinate class, often without the subordinate class's awareness and even, sometimes with their approval. Gramsci argues that many times, when the subordinate class offers resists, it is either thwarted by the dominant class or changed to their advantage (Hall \& Jefferson, 2000). Schooling and education is one manner by which this is accomplished. While in the United States, we espouse equal educational opportunities for all, in reality, that does not occur. For decades, the United States has had inequality in the state and local funding of public schools, with schools in lower socioeconomic areas not receiving equal funding when compared to schools in the more affluent socioeconomic areas (Martin, Boser, Benner, \& Baufer, 2018). Noted black feminists Darling Hammond (1998) states

educational outcomes for minority children are much more a function of their unequal access to key educational resources, including skilled teachers and quality curriculum, than they are a function of race. In fact, the U.S. educational system is one of the most unequal in the industrialized world, and students routinely receive dramatically different learning opportunities based on their social status (para. 3)

In addition to discrepancies in access to quality educational experiences, there also exists disparities among college completers, with white students in the US graduating in significantly higher numbers as compared to many students of color (Libassi, 2008). In fact, one of the factors that interferes with 
refugees' success in schooling is discrimination as well as lack of access to appropriate education for nonEnglish speakers (Nwosu \& Barnes, 2014).

As a professor working with pre-service teachers in a state that is the fourth highest in percentage the whites in the United States (Kaiser Foundation, 2014), I have worked extensively with students with little access to experiences with students, neighbors, and friends of varied ethnicity. In discussions about the source of their knowledge, it is revealed that it often comes from their families, media, or perhaps, from one or two students of color in their school. When I introduce topics in my women and gender studies courses that include the voices of white women, women of color, historical events that impacted society, other than wars and domination, in which women played an important role, students frequently are outraged, and ask why they were not taught about these things in their years of education prior to their undergraduate education. I return to the ideas of Freire and Gramsci, and we highlight important questions about the content and the purpose of school curriculum. These are questions that apply to all of us, as global citizens, and formal and informal educators. These questions are:

- Who determines what curriculum we must teach and what curriculum is given more emphasis?

- Who derives significant benefits from learning this curriculum?

- Who or what is neglected when we teach this curriculum?

- Who or what may be impacted in a negative manner by these educational approaches?

- Whose voices are not represented in our curriculum? Why?

When Freire (2000) was working with the approved state curriculum to teach his group of illiterate peasants, he found that the state curriculum was completely unrelated to the actualities of his students' lives. So, instead - he worked with what these students knew; they learned to read and write by working with subjects to which they could relate, in this case, farming and agriculture.

This is the crux of the matter... if the emphasis of our teaching our students, whether they be future teachers, future business leaders, or future scientists, is to provide them with material to which they can relate, how do we provide counternarratives to what they are hearing in the news and other media sources - especially if these students are from very homogenous, non-diverse backgrounds? It has been my experience that this cannot be done with traditional approaches. Freire (2000) provides a significant critique of lectures and/or the banking system of education, whereby the all-powerful teacher determines what must be learned, and drops these deposits of knowledge into her/his students' minds with little to no acknowledgement of the students' experiences and own personal knowledge. Changing this approach to a more student centered, collaborative educational environment can create engaged, empowered students with a deeper commitment towards their future work with individuals from a wide realm of backgrounds in this increasingly globalized world. This approach is may be met with resistance, by students and other faculty and administrators, especially when working in areas deconstructing some societal norms and values. As students engage in these classes, often after initial hesitation, they find they learn more content, and find it easier than in a traditional lecture setting. Resistance to this approach from teachers and administrators can be softened initially through a variety of methods from anecdotal descriptions of class occurrences, classroom visits, to formal professional enhancement opportunities.

\section{A Pedagogy for All Students}

I have been teaching an interdisciplinary course to upper level students, many of whom are preservice teachers, for well over ten years. I combine components of feminist theory, social justice, education, and history in this course. I have used some pedagogical techniques that have evolved over time, and have been quite successful at having my predominantly white, Eurocentric students start to reframe their ideas about diversity, living in a global society, and, for those future teachers, effectively teaching students from diverse backgrounds, including refugees.

The pedagogical approach I am about to describe has its roots in Freire's work, as well the work of bell hooks, especially her classic Teaching to Trangress. Hooks $(2003,2010)$ emphasizes the importance of addressing race, class, ethnicity, and spirituality as components that impact curriculum, and these are 
critical components to include in our teaching. I also include some ideas from of my own work, looking towards the blues metaphor as a pedagogical blueprint - especially with its honesty, its discussion of topics not often highlighted in dominant society, its use of testimony, and its transformative nature (McLoughlin, 2008).

The first step in this process is examining the power structure in the room. As professors and educators, we do have the unarguable powerful role of assigning grades to our students. In addition, some universities require specific types of midterms, etc. which also places a lot of power in the hands of the professor. The question is how can we level this - allowing the students more voice? I approach this on the first day of the semester, explaining to the students that they will be learning from not only myself, but also from each other, as will I. To avoid arguments, and dominant voices overtaking the classroom (again playing with power dynamics), I carefully explain to the students that they are all coming into the classroom with their own set of truths and values, some of which may be significantly different than their peers. We discuss what has helped us develop these truths (they easily come up with life experiences, family and friends, but dig a little to talk about media - often emphasizing social media). We then grapple with how to understand that some of their peers may have very different sets of truths - and these truths are also based on their different but equally valid experiences, etc. The crux of this initial discussion is to develop guidelines on how to respect these differences and learn from them (i.e. not saying "I disagree" or you're wrong," but instead "I never thought of looking at ... this way - tell me how you've come to this idea." This approach also empowers students - it sets the groundwork for them effectively teaching one another. Students quickly agree to this approach, but they do need reminders, and we do revisit these ideas, especially before discussions that may elicit a greater variety of responses.

Clearly, we cannot rely only on large class discussions. Some students are shy. Some students, especially those of different class or ethnicity, may feel somewhat intimidated to speak up if they feel they are in a marginalized group. Hence, the structure of the classroom must change. During the first three weeks of class (which typically meets two times per week), I have the class break up into self-selected small groups of four to five students. They are given the caveat of not including people they know in the group, and having mixed majors (no more than one women and gender studies major per group), etc. Essentially, they are creating groups in which they are learning from peers with whom they have not work in the past. Their first assignment is to name their group based upon something they have in common. When we meet as a large class on campus, I make sure to utilize these group; they are assigned small group discussion times for ideas, and then the group reports out to the large group. This approach helps the quiet student have a voice. It is not as intimidating to speak to a group of three peers as compared to expressing your ideas to a group of 26 students. Moreover, they begin to know these peers - I intentionally leave a little extra "chat time" for their small group work before we return to the large group discussion.

After the first three weeks of class, one of the two days per week that we meet is done on-line with their small group, essentially creating a blended approach. For the on-line day, students write a solid response to their reading - not a summary of their assigned reading, but their responses to what they read,backed up by their experiences. Then they must respond to two of their peers' responses. I am always amazed at how well they learn from each other, help explain their interpretation of some theoretical ideas, and support one another in these posts. I review all their posts before the next on campus class, and make sure to clarify areas of confusion, but usually this is rare. Again, teaching this way shifts some of the power to them - they are responsible for learning and helping their peers learn.

I also provide a space for them to share their individual voice only with me; individual reflections are passed in off and on throughout the semester. When students write ideas that stray from principles of equality, I respond with a question in the margins ... "Have you considered this idea using this type of lens?" or "tell me how you came to this conclusion? How do you think those who think in opposite manner may have reached their conclusions?" As their professors, we need to remember we are guiding them on their personal journey, and students travel at their own unique pace, and start at different positions. 
Finally, I have to remember many of my students have very little exposure to diversity. I give personal testimonies of my intercultural works, with honest examples of how I battle my lack of knowledge and occasional trepidation of living and working in different cultures. I tell them anecdotes of the hardships some of my friends of color have endured, but do not choose to share with man white folks. This modeling often has them come up with personal stories of marginalization for a variety of reasons, and helps them identify commonalities and connections with those about whom they had not even considered due to limited experiences.

Another manner by which I expose them to new ideas is through videos. Ted Talks often are well received, but a good topic search can often bring forth three or four short but provocative videos related to the topic they are studying. Taking short "pair and share" or small group discussion times after each clip helps reinforce ideas, and elicit areas of confusion. This is another means of providing a safe space for those students who may be shy and hesitant about speaking in a large group.

As with most course, students also have a couple formal papers in which they are examining topics via differing lenses. For example, in their "Differing Perspectives" paper, they are to examine several different subgroups of feminism - black feminism, indigenous feminism, Islamic feminism, etc. They write up their own ideas about feminism, including references to other scholars' overall definition of feminism. They then compare the more traditional "white feminist" lens to the lenses of two subgroups of feminism. This allows them to become accustomed to viewing important concepts from differing angles it provides them with the impetus not to take what they hear or read through the media and/or family members, friends, etc. at face value. It encourages critical thinking, having them become better listeners and stronger consumers of media and its associated rhetoric. They start to question "Why is it this way? Who does this policy help? Who is not helped or maybe even harmed by a policy?" It chips away at the core of some of our societal assumptions.

\section{CONCLUSION}

How does this relate to our work with refugees and immigrants? I believe by incorporating components of these approach in learning more about refugees, and deconstructing the stereotypes we so often hear or see from personal interactions and from the media, we begin to have our students (and perhaps our peers through less formal educational moments) connect and find commonalities. Instead of looking at refugees through stereotypical lenses, they begin to see refugees as individuals, often facing tremendous challenges upon which we do not to add discrimination and biases. They often begin to take on the role of activists - not necessarily marching and demonstrating but volunteering for opportunities that may help refugees, immigrants or other marginalized individuals in our society. They also begin to expose their friends and family members to their new approaches at examining this concern.

Not all of us have the luxury of teaching a course specifically about the refugee diaspora. However, much like I intertwine components of feminist theory and social justice into nearly all of my coursework, I believe we must find spaces in our formal and informal teaching to include education about refugees in as well. This does not mean only in countries where a large number of refugees have entered. This is a global concern about which we need to educate all our students.

We need to recognize that education is a manifestation of power; as formal and informal educators, we are in very powerful positions to develop future change makers. We need to have courage and ingenuity in developing and/or adapting courses to engage in important issues beyond the mainstream

curriculum. By utilizing some the teaching approaches, I have found helpful, we are taking strong steps to help address the complexities surrounding responses and support of refugees in today's world. 


\section{REFERENCES}

Crenshaw, K. (2017, June 8). Kimberly Crenshaw on intersectionality, more than two decades later. Columbia Law School. New York: Trustees of Columbia University. Retrieved from https://www.law.columbia.edu/pt-br/news/2017/06/kimberle-crenshaw-intersectionality

Crenshaw, C., Gotanda, N., Peller, G., \& Thomas, K. (Eds.). (1995). The intersection of race and gender. In Critical Race Theory: Key Writings that Formed the Movement (pp. 357-383). New York: The New Press.

Freire, P. (2000). Pedagogy of the oppressed (30th anniversary ed.). New York: Continuum. Originally published 1970.

Giroux, H. (2005). Border crossings: Cultural workers and the politics of education. New York: Routledge.

Hall, S., \& Jefferson, T. (Eds.). (2000). Resistance through rituals: Youth subculture in Post War Britain (5th ed.). London: Routledge.

Hammond, L. D. (1998). Unequal opportunity: Race and education. Brookings. Retrieved from https://www.brookings.edu/articles/unequal-opportunity-race-and-education/

Hooks, B. (1994). Teaching to transgress: Education as the practice of freedom. New York: Routledge.

Hooks, B. (2010). Teaching critical thinking; Practical wisdom. New York: Routledge.

Kaiser Foundation. (2017). Population distribution by race/ethnicity. State Health Facts. Retrieved from: https:/www.kff.org/other/stateindicator/distributionbystateethnicity/?currentTimeframe=

Kisiara, O. (2015). Marginalized at the centre: How public narratives of suffering perpetuate perceptions of refugees' helplessness and dependency. Migration Letters, 12(2), 162-171. Retrieved from http://search.ebscohost.com/login.aspx?direct=true $\& \mathrm{db}=\mathrm{a} 9 \mathrm{~h} \& \mathrm{AN}=102305130 \&$ site $=$ ehostlive \&scope $=$ site

Krenshaw, K. (2009). Mapping the margins: Intersectionality, identity politics, and violence against women of color. In E. Taylor, D. Gillborn, \& G. Ladson-Billings (Eds.) Critical race theory (pp. 213-246). New York: Routledge.

LiBassi, C. J. (2008). The neglected college race gap: Racial disparities among college completers. Center for American Progress. Retrieved from https://www.americanprogress.org/issues/educationpostsecondary/reports/2018/05/23/451186/neg lected-college-race-gap-racial-disparities-among-college-completers

Martin, C., Boser, U., Benner, M., \& Baffour, P. (2018). A quality approach to school funding: Lessons learned from school finance litigation. Center for American progress. Retrieved from: https://www.americanprogress.org/issues/education-k-12/reports/2018/11/13/460397/qualityapproach-school-funding/

McDonald, E., \& O'Sullivan, M. (2018). Protecting vulnerable refugees: Procedural fairness in the Australian Fast Track regime. University of New South Wales Law Journal, 41(3).

McLaren, P. (2015). Pedagogy of insurrection: From resurrection to revolution. New York: Peter Lang.

McLoughlin, S. (2008). A pedagogy of the blues. Taipei, Rotterdam: Sense.

McLoughlin, S. (2011). Paper presentation. Teaching about diversity: Effects of utilizing different delivery models. The $11^{\text {th }}$ Annual International Conference in Diversity in Organizations, Communities, and Nations, Cape Town, South Africa.

Nwoshu, O., \& Barnes, S. (2014). Where 'Difference is the norm': Exploring refugee student ethnic identity development, acculturation, and agency at Shaw Academy. Journal of Refugee Studies, 27(3).

United Nations Higher Commission for Refugees. (2018). Retrieved from https://www.unrefugees.org/refugee-facts/statistics/

Yotebieng, K. A. (2017). Health, well-being, and urban refugees and asylum seekers: an agenda paper. Migration Letters, 14(3), 343-354. Retrieved from http://search.ebscohost.com/login.aspx?direct=true \&db=a9h\&AN=127733013\&site=ehostlive $\&$ scope $=$ site 